\title{
Acute - Toxicity, Anti-Inflammatory and Anti-Diarrhoeal Activity of Ailanthus excelsa in Mice and Rats
}

\author{
Dr. R. K. Singh \\ Associate-Professor of Zoology, Faculty of Life-Sciences, \\ Dr. C.V. Raman University, Kargi -road, Kota, Bilaspur, Chhattisgarh, India \\ rk20singh@gmail.com
}

\begin{abstract}
Ailanthus excelsa (Stem bark) are used in folk medicine for a treatment of inflammation, arthritis, expectorant, stimulant and asthma. Acute toxicity study of A. excelsa stem bark was performed on mice (Swiss) and albino rats (Wistar strain),given single doses 1,10, 50, 100,1000 and 2000mg/kg,po. showed normal behavior and no mortality up to 14 days except 500,1000 and 2000mg/kg dose 20\%, 60.0\% \&100\% mortality recorded respectively. A. excelsa (10-50x7days or 10,50 and100mg/kg, po single dose ), pretreatment time, 60 min showed significant sub-acute anti-inflammatory protection against Cotton pellet induced granuloma formation, no analgesic activity, pentobarbitone induced sleeping time reduced insignificantly, decreased swim stress immobility in mice indicating some degree of antidepressant activity. A. excelsa exhibited significant inhibitory activity against castor oil -induced diarrhoea and significant reduction in gastrointestinal motility in the activated charcoal meal in rats. The steroids, glycosides, alkaloids, and flavonoids present in the plant appear to be of chemotherapeutic interest.
\end{abstract}

Keywords: Ailanthus excelsa, Acute- toxicity, Anti-inflammatory, Diarrhoea, Swim- stress immobility, Motility

\section{INTRODUCTION}

Ailanthus excelsa Roxb ( Family: Simaroubaceae) is commonly known as Aralu, which is found in various parts of India . Ailanthus species is worldwide distributed from India, Sri Lanka, Japan, China, Australia and Sudan. In relation to India it grows in Gujrat, Rajasthan, Bihar, Orrisa, M.P. and Maharastra, Karnataka and Tamilnadu [1]. A. excelsa Roxb stem bark have employed as a folk medicine remedy for inflammation and rheumatoid [2,3] antipyretic, antifertility, antifungal, antimalarial and antibacterial activities [4,5]. A. excelsa has a role in treatment of diabetes [4]. Ethanolic extracts of $A$. excelsa reported phytotoxic, cytotoxic and insecticidal activities [4]. A. excelsa root bark showed antioxidant activity,anti-cancer activity [5,6] Three flavonoids and two sitosterols were isolated from leaves and stem bark of A. excelsa [7].This genus was found to contain flavonoids ,quercetin, alkaloids, anthraquinones [8], oils, steroids and glycosides [9]. Species of A. excelsa from leaves isolated flavonoids with anti-oxidant properties, [9].

The present investigation was conducted to study in detail A. excelsa (Stem bark) in view of its medicinal importance in folklore medicine.

\section{Materials AND Methods}

\subsection{Animal and Drug Administration}

After approval of Institutional Animal Ethical Committee (IAEC), the present study was conducted in the Department of Pharmacology, NRIADD, Kolkata on inbred Albino mice (Swiss) 15-20g and Albino rats ( Wistar Strain)100-200g . They were kept in the departmental animal house in individual cages at an ambient temperature of $26 \pm 3^{\circ} \mathrm{C}$ and 60 - 70\% relative humidity with $12 \mathrm{~h}: 12 \mathrm{~h}$ light: dark cycles. They had fee access to standard rodent pellet diet (NIN, Hyderabad) and drinking water (Kinley) during the entire study period. The food was withdrawn $18 \mathrm{~h}$ prior to experiment /surgical procedure, however, water was allowed ad libitum.

\subsubsection{Plant Material}

The Ailanthus excelsa (Stem bark) was obtained from the Regional Research Centre (Ay) Patna,Bihar,India and identified in the Department of Pharmacognosy, NRIADD, Kolkata, peripheral 
Institute of Central Council for Research in Ayurvedic Sciences, Govt.of India. A few mg of powdered drug was warmed with Chloral hydrate, washed and mounted in glycerine. A few $\mathrm{mg}$ of powder was cleared in $4 \% \mathrm{KOH}$, washed and mounted in glycerine. A few mg of powder was washed in plain water, a drop of KI -solution was added and mounted. Camera Lucida drawings were done for the salient features of the drug. The voucher specimens have been preserved.

\subsubsection{Extraction}

Dried powdered $(500 \mathrm{~g})$ A. excelsa were extracted by ethanol, and concentrated in a steam bath to a final yield of $80.0 \mathrm{~g}(16.0 \% \mathrm{w} / \mathrm{w})$. Chemical tests showed the presence of glycosides, steroids, alkaloids and flavonoids.

\subsubsection{Acute-Toxicity Studies on Mice}

Albino mice (Swiss: $2 \mathrm{M}+3 \mathrm{~F}=5$ ) weiging $15-20 \mathrm{~g}$ were given graded doses of $A$. excelsa at the dose level of 1,10, 50,100,200,500,1000 and 2000mg/kg,po and with Control. These animals were fasted $18 \mathrm{~h}$ prior to the experimentation. Both the test and control groups were received in a same volume of drug or vehicle control as per body weight. Experiments were conducted as per OECD guidelines423(Acute-Oral Toxicity-Single Dose) [10]. The animals were kept in observation for 96h upto 14 days for any gross behavioral changes and mortality. The animals were observed for symptoms ie writhing pilo-erection, salivation fur, lacrimation, convulsion, hyperreactivity etc continuously for the first $4 \mathrm{~h}$ after dosing. The numbers of survival were noted after 24h.These animals were then maintained and observed daily for 14 days for further any toxicity. Complete postmortem was done on all survivors or if any animal found dead or moribund condition during the study period. Histopathological examination was performed on all collected tissues of individual animals.

\subsubsection{Acute-Toxicity Studies on Rats}

Albino rats (Wistar strain: $2 \mathrm{M}+3 \mathrm{~F}=5$ ) weiging $100-120 \mathrm{~g}$ were given graded doses of A. excelsa at the dose level of 1, 10,50, 100,200,500, 1000 and $2000 \mathrm{mg} / \mathrm{kg}$,po and with Control. These animals were fasted $18 \mathrm{~h}$ prior to the experimentation. Experiments were conducted as per OECD guidelines423(Acute-Oral Toxicity-Single Dose) [10]. The animals were kept in observation for $96 \mathrm{~h}$ upto 14 days for any gross behavioral changes and mortality.

\subsection{Anti -Inflammatory Activity (Cotton Pellet Granuloma Pouch)}

Albino rats (Wistar Strain) weighing 150-200g were divided into 4 groups (N=6).Group I received double distilled water DDW(Control), Group II received Diclofenac sodium (13.5mg/kg,po) served as Standard Control and Group III and IV was given A. excelsa at the dose level of $10 \& 50 \mathrm{mg} / \mathrm{kg}$, po X 7days.Cotton pellet was weighed $20 \mathrm{mg}$ sterilized and in a hot air oven at $120^{\circ} \mathrm{C}$ for $2 \mathrm{~h}$, then implanted bilaterally in region of rat under light ether anesthesia and stitched properly [11] . At the end of drug treatment cotton pellet were taken out by dissection, placed in petri dish and placed in $70^{\circ} \mathrm{C}$ oven for over- night and weight after cooling. Increase in the dry weight of the pellets was taken as measure of granuloma formation and compared with Control and Standard Control. Cotton pellet induced granuloma the average weight of the pellets of the Control group and Standard control as well as of the test group was calculated. The percent change of granuloma weight relative to control group was determined.

\subsection{CNS Activity}

\subsubsection{Analgesic Activity (Writhing-Test)}

The male mice $(\mathrm{N}=6$ in each group) were pretreated with $A$. excelsa at the dose level $(10,50 \&$ $100 \mathrm{mg} / \mathrm{kg}$,po ) and Control group received (DDW) $60 \mathrm{~min}$ prior to the experiments. The writhing induced by freshly prepared $0.6 \%$ Acetic acid (ip) in mice within 3-10 min. The number of writhing of the abdominal musculature and extension of the hind limbs were recorded for $10 \mathrm{~min}$ [12].

\subsubsection{Swim Stress Immobility in Mice}

The mice $(\mathrm{N}=5$ in each group) pretreated with $A$. excelsa at the dose level $(10,50$ and $100 \mathrm{mg} / \mathrm{kg}, \mathrm{po})$ and Control group received (DDW) $60 \mathrm{~min}$ prior to the experiments. Mice were made to swim in a $7 \times 8 \times 24$ inch Perspex cage filled with water at $30^{\circ} \mathrm{C}$ for $15 \mathrm{~min}$ [13]. The immobility phase of each mouse was recorded and compared with that of the control.

\subsubsection{Pentobarbitone $(P B)$ hypnosis}

The male rat ( $\mathrm{N}=6$ in each group) were pretreated with $A$. excelsa at the dose level $(10,50$ and100 $\mathrm{mg} / \mathrm{kg}$,po ) and Control group received (DDW) $60 \mathrm{~min}$ prior to the experiments. Each animal was 
injected with pentobarbitone sodium $(35 \mathrm{mg} / \mathrm{kg}$,ip) to study any significant change in sleeping time by A.excelsa [14]. The experiments were conducted at an ambient temperature of $20^{\circ} \pm 2^{0} \mathrm{C}$.

\subsection{Castor Oil -Induced Diarrhoea in Rats}

Albino rats (Wistar Strain) weighing 100-120g were divided into 5 groups $(\mathrm{N}=3 \mathrm{M}+3 \mathrm{~F}$ in each group).Group I received double distilled water DDW(Control), Group II received Diphenoxylate $(5 \mathrm{mg} / \mathrm{kg}, \mathrm{po})$ served as Standard Control and Group III, IV and V was given A. excelsa at the dose level of 10,50 and $100 \mathrm{mg} / \mathrm{kg}$, po. were fasted for $18 \mathrm{~h}$ prior to the experiment. One hour after treatment, each group of animals received $1 \mathrm{ml}$ of castor oil po and then defection was observed up to $4 \mathrm{~h}$. The presence of characteristic diarrhoeal droppings of individual animal was recorded $[15,16,17]$.

\subsection{Gastrointestinal Motility in Rats}

Albino rats (Wistar Strain) weighing 100-120g were divided into 5 groups $(\mathrm{N}=3 \mathrm{M}+3 \mathrm{~F}$ in each group).Group I received double distilled water DDW(Control), Group II received atropine sulphate $(0.1 \mathrm{mg} / \mathrm{kg}$,ip) served as Standard Control and Group III, IV and V was given A. excelsa at the dose level of 10,50 and $100 \mathrm{mg} / \mathrm{kg}$, po. were fasted for $18 \mathrm{~h}$ prior to the experiment. Each animal was administered with $1 \mathrm{ml}$ of charcoal meal po (3\% deactivated charcoal in DDW). After 30 min each animal was sacrificed and the intestinal distance moved by the charcoal meal from the pylorus was cut and measured and expressed as a \% of the distance from pylorus to the caecum [18].

\subsection{Statistical Analysis}

All the data was analyzed by student's t-test followed by ANOVA.

\section{RESUlTS AND DisCUSSION}

\subsection{Acute-Toxicity Studies on Mice}

All animals treated with different doses of A. excelsa showed normal behavior and No mortality was recorded up to 14 days, except 500,1000 and $2000 \mathrm{mg} / \mathrm{kg}$ dose $20 \%, 60.0 \% \& 100 \%$ mortality recorded respectively. After postmortem, histopathological examination was performed, actual route cause of mortality is higher exposure of dose.

\subsection{Acute-Toxicity Studies on Rats}

All animals treated with different doses of $A$. excelsa showed normal behavior and No mortality recorded up to 14 days, except 500,1000 and $2000 \mathrm{mg} / \mathrm{kg}$ dose $20 \%, 40.0 \%$ and $60.0 \%$ mortality recorded respectively. After postmortem, histopathological examination was performed, actual route cause of mortality is higher exposure of dose.

\subsection{Anti -Inflammatory Activity (Cotton Pellet Granuloma Pouch)}

The results are summarized in Table 1 . A. excelsa doses 10 and $50 \mathrm{mg} / \mathrm{kg}$ significantly inhibited and compared with control and standard drug diclofenac sodium.

\subsection{CNS Activity}

\subsubsection{Analgesic Activity (Writhing-Test)}

The results are summarized in Table 2. All the doses 10,50 and $100 \mathrm{mg} / \mathrm{kg}$ showed insignificant writhing against $0.6 \%$ Acetic acid (ip) (No analgesic activity).

\subsubsection{Swim- Stress Immobility in Mice}

The results are summarized in Table 3 . All the doses 10,50 and $100 \mathrm{mg} / \mathrm{kg}$ showed a tendency to decrease immobility significantly.

\subsubsection{Pentobarbitone (PB) Hypnosis}

The results are summarized in Table 4. All the doses 10,50 and $100 \mathrm{mg} / \mathrm{kg}$ showed insignificant decrease sleeping time.

\subsection{Castor Oil -Induced Diarrhoea in Rats}

The results are summarized in Table 5. All the doses of A. excelsa exhibited dose-dependent significant anti-diarrhoeal activity.

\subsection{Gastrointestinal Motility in Rats}

The results are summarized in Table 6. . All the doses of A. excelsa exhibited significantly the population of charcoal meal in rats. A. excelsa, apart from diverse uses in folk medicine, has recently 
been shown to possess anti- inflammatory, analgesic and antioxidant properties. The acute toxicity studies indicate that $A$. excelsa have a significant margin of safety in mice and rats. The present study on sub- acute anti- inflammatory activity induced by cotton pellet granuloma pouch showed significant inhibition and compare with diclofenac sodium. The Porsolt swim stress immobility model is widely used to screen anti- depressant activity .The present finding indicate that decreasing swim stress immobility may reflect the presence of antidepressant activity [13], further investigation is required to reach a definite conclusion. The data of the present study indicate that $A$. excelsa protects rat against anti-diarrhoeal activity and gastrointestinal motility .Therfore, the finding suggests a protective role of $A$. excelsa in anti-inflammatory activity $[2,3]$ anti-diarrhoeal activity and intestinal motility $[\mathbf{1 9 , 2 0}]$. This finding is justify the traditional use for the treatment of arthritis and management of diarrhoea.

Table1. Anti-inflammatory effects of A. excelsa by Cotton Pellet- induced Granuloma pouch Weight. Values are mean \pm SE Weight (mg. Figures in parentheses indicate number of animals used.

\begin{tabular}{|c|c|c|c|}
\hline Treatment $(\mathrm{mg} / \mathrm{kg}, \mathrm{po})$ & $\mathbf{N}$ & Weight of dry Cotton Pellet Granuloma & $\%$ inhibition \\
\hline Control (DDW) & 6 & $26.31 \pm 0.02$ & - \\
\hline DICLOFENAC SODIUM 13.5 & 6 & $11.24 \pm 0.06^{\mathrm{a}}$ & $57.27^{\mathrm{b}}$ \\
\hline A. excelsa & 6 & $18.13 \pm 0.03^{\mathrm{a}}$ & $31.09^{\mathrm{b}}$ \\
\hline 50 & 6 & $10.64 \pm 0.01^{\mathrm{a}}$ & $59.56^{\mathrm{b}}$ \\
\hline
\end{tabular}

${ }^{a} p<0.001$ in respect to control, ${ }^{b} p<0.001$ in respect to Standard Control

Table2. Analgesic effects of A. excelsa by Writhing test induced by $0.6 \%$ Acetic acid in albino mice. Values are mean $\pm S E \%$ writhing. Figures in parentheses indicate number of animals used.

\begin{tabular}{|l|l|l|l|}
\hline \multicolumn{1}{|c|}{ Treatment mg/kg,po } & \multicolumn{1}{c|}{$\mathrm{N}$} & \multicolumn{1}{c|}{ \% Writhing } \\
\hline Control (DDW) & 6 & $32.16 \pm 1.61$ \\
\hline A. excelsa & 6 & 6 & $35.51 \pm 4.87^{\mathrm{NS}}$ \\
\hline 50 & 6 & $41.32 \pm 7.51^{\mathrm{NS}}$ \\
\hline 100 & 6 & $44.27 \pm 8.64^{\mathrm{NS}}$ \\
\hline
\end{tabular}

$N S=$ Not significant in respect to control.

Table3. Effect of A. excelsa on Swim stress (900s duration) in albino mice. Values are mean \pm SE immobile phase (s). Figures in parentheses indicate number of animals used.

\begin{tabular}{|c|c|c|}
\hline Treatment mg/kg,po & $\mathbf{N}$ & Swim stress immobile phase (s) \\
\hline Control (DDW) & 5 & $327.16 \pm 32.13$ \\
\hline A. excelsa & 5 & $180.49 \pm 26.07^{\mathrm{a}}$ \\
\hline 50 & 5 & $147.21 \pm 23.18^{\mathrm{a}}$ \\
\hline 100 & 5 & $139.33 \pm 20.15^{\mathrm{a}}$ \\
\hline
\end{tabular}

${ }^{a} p<0.001$ in respect to control.

Table4. Effect of A. excelsa on Pentobarbitone - induced sleeping time in male albino rat. Values are mean \pm $S E$ sleeping time ( $\mathrm{min})$. Figures in parentheses indicate number of animals used.

\begin{tabular}{|c|c|c|}
\hline Treatment mg/kg,po & $\mathbf{N}$ & Pentobarbitone- induced sleeping time (min) \\
\hline Control (DDW) & 5 & $114.75 \pm 17.32$ \\
\hline A. excelsa & 5 & $116.80 \pm 27.08^{\mathrm{NS}}$ \\
\hline 50 & 5 & $89.60 \pm 17.04^{\mathrm{NS}}$ \\
\hline 100 & 5 & $121.50 \pm 19.53^{\mathrm{NS}}$ \\
\hline
\end{tabular}

$N S=$ Not significant in respect to control.

Table5. Effect of A. excelsa on Castor oil- induced diarrhoea in rats. Values are mean $\pm S E$ defecation. Figures in parentheses indicate number of animals used.

\begin{tabular}{|c|c|c|c|}
\hline \multicolumn{2}{|c|}{ Treatment mg/kg,po } & $\mathbf{N}$ & Castor oil- induced defecation \\
\hline \multicolumn{2}{|l|}{ Control (DDW) } & 6 & $6.10 \pm 0.53$ \\
\hline Diphenoxylate & 5 & 6 & $1.42 \pm 0.45^{\mathrm{a}}$ \\
\hline \multirow[t]{3}{*}{ A. excelsa } & 10 & 6 & $3.07 \pm 0.67^{\mathrm{a}}$ \\
\hline & 50 & 6 & $2.23 \pm 0.56^{\mathrm{a}}$ \\
\hline & 100 & 6 & $1.89 \pm 0.31^{\mathrm{a}}$ \\
\hline
\end{tabular}

${ }^{a} p<0.01$ in respect to control. 
Table6. Effect of A. excelsa on gastrointestinal motility in rats. Values are mean \pm SE \% movement of charcoal meal. Figures in parentheses indicate number of animals used.

\begin{tabular}{|c|c|c|}
\hline Treatment mg/kg,po & $\mathbf{N}$ & \% Movement of Charcoal meal \\
\hline Control (DDW) & 6 & $90.25 \pm 2.27$ \\
\hline Atropine sulphate & 6 & $47.16 \pm 2.03^{\mathrm{a}}$ \\
\hline A. excelsa & 6 & $70.89 \pm 2.19^{\mathrm{a}}$ \\
\hline 50 & 6 & $49.54 \pm 1.89^{\mathrm{a}}$ \\
\hline 100 & 6 & $39.67 \pm 1.98^{\mathrm{a}}$ \\
\hline
\end{tabular}

${ }^{a} p<0.001$ in respect to control.

\section{Conclusion}

Acute toxicity of A. excelsa has safe up to the doses of $200 \mathrm{mg} / \mathrm{kg}$ and caused no mortality and normal behavior. The results of the present study reveal that significant anti- inflammatory activity, swim stress immobility anti- diarrhoeal activity and gastrointestinal motility. A. excelsa is rich in glycoside, alkaloids and flavanoids. Pure isolates of active principles need testing toward identifying steroids, glycosides, alkaloids and flavonoids present in the plant appear to be therapeutic interest for chronic arthritis treatment and management of diarrhoea.

\section{ACKNOWLEDGEMENTS}

The work was financed by Central Council for Research in Ayurvedic Sciences, Department of AYUSH, Ministry of Health \& Family Welfare, New-Delhi, Government of India.

\section{REFERENCES}

[1] Chopra,R.N. Chopra,I.C,HandaK.L. ,Kapur,L.D. Chopra's Indigenous Drugs of India,2 ${ }^{\text {nd }}$ Edn,UN Dhar and Sons,Pvt. Ltd, Calcutta,India .p408 (1958)

[2] Kirtikar,K.R. , Basu,B.D. Indian Medicinal Plants .Vol I ,International Book Distributors, Dehradun, India, p 371-372 (1995)

[3] Kirtikar,K.R., Basu,B.D. Indian Medicinal Plants $.2^{\text {nd }}$ Edn , Mohan Basu, Publisher, Allahabad,India (2003)

[4] Lavhale, M.S., Mishra, S.H. Nutritional and therapeutic potential of Ailanthus excelsa: A review.Pharmcognosy Rev., 1,105-113. (2007).

[5] Lavhale, M.S., Kumar,S., Mishra ,S.H.,Sitasawad ,S.L. A novel triterpenoid isolated from the root bark of Ailanthus excelsa Roxb (Tree of Heaven).AECHL-1 as a potential anti cancer agent PLoS One,4:e5365-E5365.(2009)

[6] Kumar ,D.,Bhat ,Z.A.,Singh,P., Shah,M.Y., Bhujbal,S.S. Ailanthus excelsa Roxb ,is Really a Plant of Heaven .Int. J. Pharmacol.6 (5),535-550 ISSN1811-7775 ( 2010).

[7] Khan,S.A., Shamsuddin, K.M. Quassinoids from Ailanthus excelsa .Ind.J.Chem,16B,1045-1046 (1978).

[8] Khan,S.A., Shamsuddin, K.M.Isolation and structure of13,18-dehydroexcelsin,aquassinoid and glaucarubol from Ailanthus excelsa .. Phytochemistry 19,2484- 2485.(1980).

[9] Yoganandam,G.P.,Periyanayagam,K., IIango, K.Protective effect of ethanolic extract of stem bark of Ailanthus excelsa Roxb against $\mathrm{CCL}_{4}$ induced hepatotoxicity in rats .Drug Invention Today, 1,28-31(2009).

[10] M. J. Derelanko and M.A. Hollingeer, Hand Book of Toxicology ,2nd Edn Chapter "Acute , Subchronic and Chronic toxicology eds. Auletta C.S., p. 69, (2002) (CRC Press, New York, Washigaton DC).(2002)

[11] Meir ,R.,Schuler,W. and Desaulles,P., Experientia,6 ,469.( 1950).

[12] Fukawa, K., Kawano,O., Hibi,M,, Misaki, N.,Ohba, S.and Hatanaka, T.,J.Pharmacol.Meth.4,251. (1980).

[13] Porsolt, R.D., Bertin A,Blavet, N.Daniel, M. and Jalfare, M.,Immobility induced by forced swimming in rats.Effects of agents which modify central catecholamine and serotonin activity.Eur.J. Pharmacol.57, 201-210.(1979).

[14] Ikeda,H.,Take,Y.,Itoh,Y.,Nagawa,Y. Jap. J. Pharmacol, 23, 77. (1973).

[15] Valette,G.,Salvant,R. Les causes de Paction de l'huile de ricin.Bull Sci. Pharmacol. 43, 111(1936) 
[16] Gaginella,T.S. Haddad, A.C.,GO,V.L.W.,Phillips,S.F.. Cytotoxicity of ricinoleic acid (Castoroil) and other intestinal secretagogues on isolated intestinal epithelial cells. J. Pharmacol.Exp.Ther., 201,259-266.( 1977).

[17] Mascolo,N, Izzo,A.A.,Autore, G. ,Barbato,F., Capasso,F. Nitric oxide and Casor oil-induced diarrhea. J. Pharmacol.Exp.Ther.268, 291-295. (1994).

[18] Macht,D.I.,Barbara-Gose,J. J.Am.. Pharm. Asso., 20,558. (1931).

[19] Mascolo,N, Izzo,A.A., Capasso, F. Castor oil induced diarrhea:involvement of nitric oxide. In Natural Drugs and the Digestive Tract, ed Capasso,F., Mascolo,N.p121-128. Rome: EMSI. (1992).

[20] Capasso, F., Mascolo,N. Izzo,A.A., Gaginella,T.S. Dissociation of castor oil-induced diarrhea and intestinal mucosal injury in rat: effect of $\mathrm{N}^{\mathrm{G}}$-nitro-L-arginine methyl ester. Br. J. Pharmacol. 113, 1127-1130. (1994).

\section{AUTHOR's BIOGRAPHY}

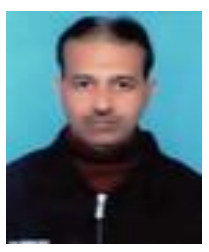

Dr. R. K. Singh, M.Sc. Ph.D. [Zoology - Pharmacology] from Dept. of Pharmacology, Institute of Medical Sciences, Banaras Hindu University of Varanasi, India. He has previously worked as a Senior Research Scientist at Department of Pharmacology, National Research Institute of Ayurvedic Drug Development, CCRAS, Department of AYUSH, Ministry of Health \& Family Welfare, New-Delhi, and Government of India. Presently working as Associate - Professor of Zoology, faculty of Life -Sciences, Dr. C.V. Raman University, Kota, Bilaspur (C.G.). He has published sixty seven papers in international and national journals on Ethno pharmacology, Cardio-Vascular Pharmacology, Neuro psycho pharmacology and Toxicology. 